\title{
A critical evaluation of arguments opposing male circumcision for HIV prevention in developed countries
}

\author{
Brian J. Morris ${ }^{a},{ }^{*}$, Robert C. Bailey ${ }^{b}$, Jeffrey D. Klausner ${ }^{c}$, Arleen Leibowitz ${ }^{d}$, Richard G. \\ Wamai $^{\mathrm{e}}$, Jake H. Waskett ${ }^{\dagger}$, Joya Banerjee ${ }^{\mathrm{g}}$, Daniel T. Halperin ${ }^{\mathrm{h}}$, Laurie Zoloth ${ }^{\mathrm{i}}$, Helen A. \\ Weiss', and Catherine A. Hankins ${ }^{k}$ \\ aSchool of Medical Sciences and Bosch Institute, University of Sydney, NSW, Australia \\ bDivision of Epidemiology and Biostatistics, University of Illinois at Chicago, Chicago, IL, USA \\ 'Department of Medicine, Division of Infectious Diseases, University of California, San Francisco, \\ CA, USA \\ ${ }^{\mathrm{d} D e p a r t m e n t}$ of Public Policy, University of California, Los Angeles, CA, USA \\ eDepartment of African-American Studies, Northeastern University, Boston, MA, USA \\ ${ }^{f}$ Circumcision Independent Reference and Commentary Service, Radcliffe, Manchester, UK \\ gGlobal Youth Coalition on HIV/AIDS, South Africa \\ hDepartment of Health Education and Health Behavior, University of North Carolina, Chapel Hill, \\ NC, USA \\ iCenter for Bioethics, Northwestern University, Chicago, IL, USA \\ jMRC Tropical Epidemiology Group, London School of Hygiene and Tropical Medicine, London, \\ UK \\ kDepartment of Infectious Disease Epidemiology, London School of Hygiene and Tropical \\ Medicine, London, UK
}

\begin{abstract}
A potential impediment to evidence-based policy development on medical male circumcision (MC) for HIV prevention in all countries worldwide is the uncritical acceptance by some of arguments used by opponents of this procedure. Here we evaluate recent opinion-pieces of 13 individuals opposed to MC. We find that these statements misrepresent good studies, selectively cite references, some containing fallacious information, and draw erroneous conclusions. In marked contrast, the scientific evidence shows $\mathrm{MC}$ to be a simple, low-risk procedure with very little or no adverse long-term effect on sexual function, sensitivity, sensation during arousal or overall satisfaction. Unscientific arguments have been recently used to drive ballot measures aimed at banning MC of minors in the USA, eliminate insurance coverage for medical MC for low-income families, and threaten large fines and incarceration for health care providers. Medical $\mathrm{MC}$ is a preventative health measure akin to immunisation, given its protective effect against HIV infection, genital cancers and various other conditions. Protection afforded by neonatal MC against a diversity of common medical conditions starts in infancy with urinary tract infections and extends throughout life. Besides protection in adulthood against acquiring HIV, MC also reduces morbidity and mortality from multiple other sexually transmitted infections (STIs) and genital cancers in men and their female sexual partners. It is estimated that over their lifetime one-
\end{abstract}

(C) 2012 Taylor \& Francis

*Corresponding author. brian.morris@sydney.edu.au. 
third of uncircumcised males will suffer at least one foreskin-related medical condition. The scientific evidence indicates that medical MC is safe and effective. Its favourable risk/benefit ratio and cost/benefit support the advantages of medical MC.

\section{Keywords}

circumcision; HIV; evidence-based evaluation; public health policy; preventative medicine

\section{Introduction}

The rise in heterosexually acquired HIV in developed countries (Centers for Disease Control and Prevention [CDC], 2011a; National Centre for HIV Epidemiology and Clinical Research [NCHECR], 2011; UNAIDS, 2010) and proof that male circumcision (MC) protects against HIV (Auvert et al., 2005; Bailey et al., 2007; Gray et al., 2007, 2012) have led to calls for increased infant MC (Cooper, Wodak, \& Morris, 2010; Tobian \& Gray, 2011; Tobian, Gray, \& Quinn, 2010; Zetola \& Klausner, 2012). Here we critique opinions of MC opponents (Boyle \& Hill, 2011; Chin, 2011; Conroy, 2011; Darby, 2011; Darby \& Van Howe, 2011; Forbes, 2011; Paix, 2011; Travis et al., 2011). These misrepresent credible research, and cite questionable websites, superseded publications, outlier studies, non-peerreviewed book chapters and discredited paediatric policy statements (Schoen, Oehrli, Colby, \& Machin, 2000; Morris, Bailis, Castellsague, Wiswell, \& Halperin, 2006; Morris et al., 2012b). Opposition to infant medical MC in the USA (Green, McAllister, Peterson, \& Travis, 2009) has seen Medicaid coverage decline, posing a danger to public health (Leibowitz, Desmond, \& Belin, 2009; Morris, Bailis, Waskett, Wiswell, \& Halperin, 2009).

Boyle and Hill (2011) and Darby and Van Howe (2011) repeat claims opposing medical MC for HIV prevention in sub-Saharan Africa (Gisselquist et al., 2009; Green, McAllister, Peterson, \& Travis, 2008; Green et al., 2010; Van Howe, 1999; Van Howe \& Storms, 2011) shown previously to be seriously flawed (Banerjee et al., 2011; Morris et al., 2011b; Moses, Nagelkerke, \& Blanchard, 1999; O'Farrell \& Egger, 2000; Wamai et al., 2008, 2011; Wamai $\&$ Morris, 2011; Wawer et al., 2011). A dated opinion piece by Fleiss, Hodges, and Van Howe (1998) cited by Paix (2011) contradicts research. Van Howe's other anti-MC claims have been refuted (Bailis, 1998; Castellsague, Albero, Cleries, \& Bosch, 2007; Schoen, 1997, 2007; Waskett \& Morris, 2007, 2008; Waskett, Morris, \& Weiss, 2009). Contrary to Darby and Van Howe (2011)'s claim that 'it will be many years before we learn whether the current African circumcision programs have succeeded", a large-scale MC roll-out has demonstrated $76 \%$ HIV protection (Auvert et al., 2011).

\section{Sexual function, sensation and satisfaction}

Claims that MC is "highly mutilating", "seriously impairs penile function" (Paix, 2011) and "amputates healthy, functional, protective, erogenous tissue" (Boyle \& Hill, 2011) have led vulnerable men to falsely believe their sexual problems stem from their infant circumcision, leading them to "feel angry and mutilated, even to the point of psychological disturbance" (Darby \& Van Howe, 2011), resorting to mutilating "foreskin restoration" (Walter \& Streimer, 1990). In reality, sexual dysfunction, especially with age, is either more common (Laumann, Maal, \& Zuckerman, 1997; Richters, Smith, de Visser, Grulich, \& Rissel, 2006) or no different (Collins et al., 2002; Ferris et al., 2010; Masood et al., 2005) in uncircumcised versus circumcised men.

Empirical measurements show no difference in penile sensitivity (Bleustein, Fogarty, Eckholdt, Arezzo, \& Melman, 2005; Collins et al., 2002; Masters \& Johnson, 1966), 
sensation during arousal (Payne, Thaler, Kukkonen, Carrier, \& Binik, 2007), sexual satisfaction (Collins et al., 2002; Fink, Carson, \& deVellis, 2002), premature ejaculation (Son, Song, Kim, \& Paick, 2010) or intravaginal ejaculatory latency time (Waldinger et al., 2005; Waldinger, McIntosh, \& Schweitzer, 2009). Sexual satisfaction may increase (Senol, Sen, Karademir, Sen, \& Saraçoğlu, 2008), with randomized controlled trials (RCTs) confirming similar or enhanced sexual function, sensitivity and satisfaction in men and their wives (Breda, 2011; Kigozi et al., 2008; Krieger et al., 2008; Westercamp, Bailey, \& Agot, 2011).

Travis et al. ignore these, instead citing Sorrells et al. (2007), a discredited study with erroneous statistics (Waskett \& Morris, 2007). Similarly Forbes (2011) cites a Korean study (Kim \& Pang, 2007) also discredited (Willcourt, 2007), as have others (Morris, Waskett, \& Gray, 2012).

US men ranked the ventral surface of the penis highest for "sexual pleasure" and "orgasm intensity", followed by the upper surface and sides, the foreskin being less important (Schober, Meyer-Bahlburg, \& Dolezal, 2009). Sexual sensation is mediated by genital corpuscles, but these are absent from the foreskin (Rhodin, 1974). Penile sensitivity decreases during arousal, as appropriate for penetration (Payne et al., 2007). In circumcised men arousal response is quicker.

\section{Deaths from infant MC}

The claim by Travis et al. of " 0.9 deaths per 10000 circumcisions" is from Bollinger (2010), who assumed sex differences in infant mortality in the USA are entirely due to MC. But sex differences are also seen in countries with low neonatal MC (Table 1). The cause is multifactorial (Drevenstedt, Crimmins, Vasunilashorn, \& Finch, 2008),

Deaths from medical MC are exceedingly rare, as Darby and Van Howe (2011) confirm. They are mostly from general anaesthesia, local anaesthesia being safer.

\section{HIV infection in men}

Travis et al. (2011) and Darby and Van Howe (2011) falsely dismiss MC for HIV prevention in the USA, failing to acknowledge that most incident HIV infections are in menwho-have-sex-with-men (MSM), via receptive anal intercourse, a mode unaffected by MC. Boyle and Hill (2011) fail to recognise that HIV is nevertheless lower in "insertive only" MSM (Buchbinder et al., 2005; Fox, 2007; Kreiss \& Hopkins, 1993; Millett, Flores, Marks, Reed, \& Herbst, 2008; Templeton et al., 2009; Wiysonge et al., 2011). HIV risk and vulnerability are multifactorial, including levels of sex education and condom usage (Brick, 1999; David, Morgall, Osler, Rasmussen, \& Jensen, 1990; Dodge, Sandfort, Yarber, \& de Wit, 2005; Michael et al., 1998; Wallace \& Vienonen, 1989; Weinberg, Lottes, \& Aveline, 1998). Countries with superior health care have greater testing, diagnosis and treatment, longer survival and thus higher HIV statistics.

Heterosexual US men have lower HIV prevalence if circumcised (Kassler \& Aral, 1995; Moses, Bailey, \& Ronald, 1998; Smith et al., 2010; Sullivan et al., 2007; Telzak et al., 1993; Tobian et al., 2010; Warner et al., 2009). RCTs are not needed in developed countries, given supportive observational data (Lie \& Miller, 2011). Since most US males are circumcised as infants, the claim that "there is no hard evidence that neonatal circumcision has any protective effect against acquiring HIV" (Darby, 2011; Darby \& Van Howe, 2011) is specious. High US medical MC may have moderated HIV prevalence (Addanki, Pace, \& Bagasra, 2008). Each year 1.2 million boys (55-56\%) are circumcised before hospital discharge (CDC, 2011b; Merrill, Nagamine, \& Steiner, 2008), then others post-discharge. 
Regional differences of 75\%-31\% are from Hispanic births (Merrill et al., 2008). A reduction in reimbursement by public and private health insurance (Clark, Kilmarx, \& Kretsinger, 2011; Leibowitz et al., 2009; Morris et al., 2009), and a decline in medical MC rate, could reverse the benefit experienced in the USA to date (Sullivan et al., 2007). In Australia, the decline in MC from high pre-1970s levels to only $27 \%$ in 16-19-year-olds currently (Ferris et al., 2010) should ring alarm bells (Cooper et al., 2010).

Rather than "the jury [being] still out" (Conroy, 2011) or medical MC being "irrelevant" (Darby, 2011) for HIV prevention amongst heterosexuals in developed countries, in the USA 9.6\% of new HIV cases in 2009 were from heterosexual intercourse (CDC, 2011a), and in Australia all HIV-positive heterosexual male STI clinic attendees acquired HIV from heterosexual contact, not injecting drug use (Figure 33 of NCHECR (2011)). Darby and Van Howe (2011) seem unaware that unlike MSM, who get tested frequently, heterosexuals do not (NCHECR, 2011), so most presenting with a sero-conversion illness have not previously been tested. Rather than " 23 men newly infected in 2009", Table 1.1 .6 of the 2010 NCHECR report Darby \& Van Howe cite states 155 were newly infected in 2009, with a steady rise from 88 in 2005. The NCHECR reports $23 \%$ (not "10\%") of infections were from heterosexual contact in 2009. Of these, $47 \%$ were in heterosexuals neither from, nor having a partner from, a high prevalence country. Australian-born individuals accounted for $31 \%$ of the heterosexual total. Their statement that infant MC for HIV prevention "would be ruled out on cost-benefit considerations alone" is inconsistent with public health policies that include childhood vaccinations. A pertinent example is costly vaccination programs for school girls against HPV, also acquired sexually, to reduce later cervical cancer in a small minority (Maine, Hurlburt, \& Greeson, 2010). HIV prevalence in sub-Saharan Africa in the early 1980s was similarly low. If MC programs had been implemented earlier millions of lives and dollars would have been saved (Potts et al. 2008; Potts, Prata, Walsh, \& Grossman, 2006).

Using almost identical wording, Travis et al. (2011) and Darby and Van Howe (2011) say that "African Americans have the highest rates of both circumcision and heterosexually transmitted HIV infection". Although annual HIV diagnoses in African-Americans are seven times higher than whites, $25 \%$ from heterosexual contact (CDC, 2007), the MC figures they quote of $66.2 \%$ for Blacks and $60.0 \%$ for whites were San Francisco STD clinic data (Mor, Kent, Kohn, \& Klausner, 2007), whereas representative national data show $89 \%$ of nonHispanic white and 73\% of Black men are circumcised (Xu, Markowitz, Sternberg, \& Aral, 2007). Whites (15 per 100,000) have the lowest heterosexually acquired HIV (CDC, 2011a); Black men the highest (466 per 100,000).

Darby and Van Howe (2011) distort the biological evidence of risk posed by the foreskin, even falsely claiming "the inner foreskin secretes langerin, which is effective in killing numerous pathogens". Langerin is not secreted. Langerin's function and biological reasons for foreskin risk are detailed in a recent review (Morris \& Wamai, 2012).

\section{Other sexually transmitted infections (STIs)}

Forbes (2011) claims that "evidence of the protective effect of circumcision against other sexually transmitted infections in Australia is limited". Such obfuscation (because relevant data for Australia is lacking) misrepresents the strong evidence that MC protects against oncogenic types of human papillomavirus (HPVs) (Albero, Castellsagué, Giuliano, \& Bosch, 2012; Larke, Thomas, Dos Santos Silva, \& Weiss, 2011a; Morris et al., 2011a), herpes simplex virus type 2 (HSV-2) (Cherpes, Meyne, Krohn, \& Hiller, 2003) and various other STIs in heterosexual men and their female partners in other developed, as well as developing, countries (Morris \& Castellsague, 2011; Tobian et al., 2010; Tobian \& Gray, 
2011). History of STI amongst circumcised men was 3-fold lower in a longitudinal New Zealand study (Fergusson, Boden, \& Horwood, 2006) and 2-fold lower amongst MSM in London gyms (Thornton, Lattimore, Delpech, Weiss, \& Elford, 2010). In the USA syphilis was half as common in circumcised MSM (Jameson, Celum, Manhart, Menza, \& Golden, 2010), and for insertive-only MSM was completely absent in Seattle (Jameson et al., 2010) and 10-fold lower in Sydney (Templeton, Millett, \& Grulich, 2010). Circumcised Australian heterosexual men had 50\% lower thrush (Ferris et al., 2010; Richters et al., 2006).

\section{HIV risk to women}

Boyle and Hill (2011) and Forbes (2011) claim that MC increases transmission of HIV to women, selectively citing a study of HIV-positive men who resumed sex before complete wound healing (Wawer et al., 2009). Even then, the increase was not statistically significant. Resuming sex too soon does pose a potential risk. By performing circumcision in infancy (no risk of sexual HIV acquisition) the issue of healing in a sexually mature male does not arise.

Contrary to what Forbes and Boyle and Hill state, MC confers long-term indirect and potential direct positive impacts on women (Hankins, 2007). The indirect effects come from lowering of HIV prevalence in men (UNAIDS/WHO/SACEMA Expert Group on Modelling the Impact and Cost of Male Circumcision for HIV Prevention, 2009). A metaanalysis found $20 \%$ lower HIV in the female partners of HIV-positive circumcised men (Weiss, Hankins, \& Dickson, 2009), being 38\% lower subsequently (Baeten et al., 2010). In a general population setting, modelling predicted MC would lower male-to-female HIV transmission by $46 \%$ (Hallett et al., 2011).

\section{Condoms}

Travis et al. (2011) argue that "condoms are 95 times more effective" than MC, but misquote their own article that actually states condoms are "95 times more cost effective" (McAllister, Travis, Bollinger, Rutiser, \& Sundar, 2008). They also say "a circumcision program would be five times more costly than providing free condoms". A systematic review of cost-effectiveness studies (Galárraga, Colchero, Wamai, \& Bertozzi, 2009) offers no support for this claim, even for the African HIV epidemic. Moreover, medical MC is a one-time, permanent procedure that confers lifelong $75 \%$ protection against HIV, whereas condoms must be used correctly and consistently for an entire lifetime each time a person has sex with a partner not assured of being HIV negative.

The cost of neonatal MC in the USA averages $\$ 165$, whereas cost later in childhood or adulthood is much greater (Schoen, Colby, \& To, 2006). The annual cost for $1.2 \mathrm{M}$ neonatal MCs in the USA is US\$150-270 million (Schoen et al., 2006). Assuming 20 million sexually active, condom-using men, 50 acts of sexual intercourse per year and $\$ 1$ per condom, unadjusted for inflation, annual national expenditure for condoms in the USA would be approximately $\$ 10$ billion. This far exceeds the annual cost of neonatal MC.

A Cochrane systematic review found condoms are $80 \%$ effective (Weller \& Davis, 2001), i.e., are only slightly more effective than MC. But whereas MC is always in place, condoms must be applied each time. The need for consistent use, even during foreplay, means condoms are often unpopular, especially within long-term sexual partnerships. In the USA $16 \%$ of men and $24 \%$ of women reported never using condoms during heterosexual sex with a non-primary partner (Sanchez et al., 2006). In Australia, amongst young people at higher risk of HIV exposure, only $25 \%$ always and $25 \%$ never, used them (Kang et al., 2006). Senior high school students exhibited rising sexual partnerships, but no rise in condom use (Agius, Pitts, Smith, \& Mitchell, 2010). Even Darby and Van Howe (2011) state that 
"sexually active adult men who have regular intercourse with numerous female partners and do not always use condoms should consider circumcision for themselves".

While condom use should be encouraged, condoms are not a magic bullet. WHO/UNAIDS recommend both MC and condoms.

\section{Delaying circumcision}

This suggestion (Chin, 2011) is unrealistic and impractical (Morris et al., 2012a; Tobian \& Gray, 2011). By circumcising in infancy the male will be equipped with substantial protection against STIs when he reaches sexual maturity. Infant MC also provides immediate protection against urinary tract infections, kidney damage, balanitis, balanoposthitis, foreskin injuries, hygiene-related problems and phimosis. Foreskin retraction difficulties cause pain, problems with urine flow and difficulty with erections in the teen years and later. Infant MC may afford greater protection against penile cancer than MC later in life (Larke, Thomas, Dos Santos Silva, \& Weiss, 2011b; Morris et al., 2011a). It is simpler, quicker, cheaper, more convenient, lower risk and provides a better cosmetic outcome than circumcision later (Morris \& Eley, 2011; Sansom et al., 2010; Schoen, Wiswell, \& Moses, 2000; Tobian et al., 2010; Weiss, Larke, Halperin, \& Schenker, 2010; WHO and JHPIEGO, 2010). Wound healing is, moreover, quicker (Bermudez, Canning, \& Liechty, 2011).

Parents must make many decisions on behalf of their children. The decision to circumcise (UNAIDS, 2007) is one of many that also includes vaccination.

\section{Cost and risk - versus benefit}

Travis et al. (2011) say MC costs more than it saves. Forbes (2011) claims, without data, that the benefits and risks are evenly balanced. Darby and Van Howe (2011), by selective citation, inflate the risks associated with infant MC. MC is cost-effective in developing countries (Uthman, Popoola, Uthman, \& Aremu, 2010), and in the USA a cost-benefit analysis by the CDC found infant MC would reduce lifetime HIV risk by $16 \%$, making it cost-saving for HIV prevention (Sansom et al., 2010). Over their lifetime one in three uncircumcised males will be affected by at least one medical condition that MC protects against (Morris et al., 2006, 2007, 2012c). Benefits exceed risks by well over 100-1 (Morris et al., 2006, 2007, 2012c). Cost-benefit should be substantial, especially given the high cost of treating genital cancers and AIDS, each more prevalent when MC is not performed.

\section{Surgical vaccine}

Darby and Van Howe (2011) criticise the term "surgical vaccine" which is used commonly when referring to $\mathrm{MC}$, saying "Circumcision provides nothing like the kind or level of protection provided by a vaccine". The $75 \%$ protection afforded by MC against HIV is on a par with influenza vaccinations (Fiore et al., 2007; Kelly et al., 2009).

\section{Ethical and legal arguments}

Arguments based on ethics, consent and other philosophical considerations, usually coupled with statements implying benefits and risks are evenly balanced (Forbes, 2011), or that MC is somehow harmful (Boyle \& Hill, 2011; Darby \& Van Howe, 2011; Paix, 2011), can be compared to the anti-vaccination lobby's dangerous misinformation that has outraged health authorities (Health Care Complaints Commission, 2010), reduced the uptake of childhood immunisation, and revitalised the spread of vaccine-preventable - and often fatal - diseases (Wallace, 2009; Wikipedia, 2011). Yet vaccination is accepted, despite higher risk of serious 
complications for some (Wikipedia, 2011) than infant MC. Like vaccination, benefits of MC exceed risks by a large margin (Morris et al., 2006, 2007, 2012b).

If prophylactic infant MC were "legal battery" (Travis et al., 2011) then court decisions reflecting this should exist. But there are none. Thus the legal system upholds the rights of parents to make decisions in the best interests of their child. The County of San Francisco Superior Court struck down a 2011 ballot initiative that would have banned MC of minors, stating that the city does not have the authority to restrict legal, medical procedures that physicians can perform with the parents' consent. This judgement was then supported unanimously by the California Senate, and signed into law by the Governor as bill AB768. When one considers the issues of "beneficence", "non-maleficence", "proportionality", "justice" and "autonomy" (Darby \& Van Howe, 2011), an impartial, evidence-based assessment leads to an affirmative conclusion favouring MC. Support for infant MC amongst informed parents is strong (Ahaghotu, Okafor, Igiehon, \& Gray, 2009; Wang, Macklin, Tracy, Nadel, \& Catlin, 2010). Any health professional who advises against infant MC risks consequences should foreskin-related medical problems, morbidity or death ensue (Russell, 2005).

\section{Distortions of evidence by MC opponents}

Conroy (2011) misquotes the report from a CDC meeting in 2007 of all relevant stakeholders (Smith et al., 2010). Van Howe presented his anti-circumcision case but his arguments did not feature in the report.

In complete contradiction to the sources he cites (CDC, 2008; Morris, 2007) Conroy makes the untenable claim that the evidence favouring MC for HIV prevention in countries like the USA and Australia is based on "opinion or other inconclusive, low-quality evidence". MC's protective effect against STIs in developed and developing countries per act of sexual intercourse is similar (Kassler \& Aral, 1995; Moses et al., 1998; Smith et al., 2010; Sullivan et al., 2007; Telzak et al., 1993; Tobian et al., 2010; Warner et al., 2009).

The Cochrane committee concluded that "inclusion of MC into current HIV prevention guidelines is warranted" and that "no further trials are required" (Siegfried, Muller, Deeks, \& Volmink, 2009). It seems, however, that there would be never enough evidence to convince opponents of MC.

\section{Conclusion}

A reasoned policy debate on MC must separate "values" discussions from factual discussions (Robert \& Zeckhauser, 2011). Scientists are trained to properly evaluate information and make evidence-based conclusions. Misinformation, distortions and specious arguments by MC opponents could subvert evidence-based policies, leading to suffering and deaths. As the late US Senator Daniel Patrick Moynihan was fond of saying, "Everyone is entitled to their own opinions, but they are not entitled to their own facts".

\section{References}

Addanki KC, Pace DG, Bagasra O. A practice for all seasons: Male circumcision and the prevention of HIV transmission. Journal of Infection in Developing Countries. 2008; 2:328-334. [PubMed: 19745498]

Agius PA, Pitts MK, Smith AM, Mitchell A. Sexual behaviour and related knowledge among a representative sample of secondary school students between 1997 and 2008. Australian and New Zealand Journal of Public Health. 2010; 34:467-481. 
Ahaghotu C, Okafor H, Igiehon E, Gray E. Psychosocial factors influence parental decision for circumcision in pediatric males of African American decent. Journal of the National Medical Association. 2009; 101:325-330. [PubMed: 19397222]

Albero G, Castellsagué X, Giuliano AR, Bosch FX. Male circumcision and genital human papillomavirus: A systematic review and meta-analysis. Sexually Transmitted Diseases. 2012; 39:104-113. [PubMed: 22249298]

Auvert B, Taljaard D, Lagarde E, Sobngwi-Tambekou J, Sitta R, Puren A. Randomized, controlled intervention trial of male circumcision for reduction of HIV infection risk: The ANRS 1265 Trial. PLoS Med. 2005; 2(e298):1112-1122.

Auvert, B.; Taljaard, D.; Rech, D.; Lissouba, P.; Singh, B.; Shabangu, D.; Lewis, DA. Effect of the Orange Farm (South Africa) male circumcision roll-out (ANRS-12126) on the spread of HIV; 6th IAS Conference on HIV Pathogenesis, Treatment and Prevention, 17-20 July; Rome, Italy. 2011; WELBC02

Baeten JM, Donnell D, Kapiga SH, Ronald A, John-Stewart G, Inambao M, Celum C. Male circumcision and risk of male-to-female HIV-1 transmission: A multinational prospective study in African HIV-1-serodiscordant couples. AIDS. 2010; 24:737-744. [PubMed: 20042848]

Bailey RC, Moses S, Parker CB, Agot K, Maclean I, Krieger JN, Ndinya-Achola JO. Male circumcision for HIV prevention in young men in Kisumu, Kenya: A randomised controlled trial. Lancet. 2007; 369:643-656. [PubMed: 17321310]

Bailis SA. Circumcision and infectious disease (Letter). The Pediatric Infectious Disease Journal. 1998; 17:762-763. [PubMed: 9726361]

Banerjee J, Klausner JD, Halperin DT, Wamai R, Schoen EJ, Moses S, Bowa K. Circumcision denialism unfounded and unscientific. [Critique of Green et al., "Male circumcision and HIV prevention: Insufficient evidence and neglected external validity"]. American Journal of Preventive Medicine. 2011; 40:e11-e12. [PubMed: 21335254]

Bermudez DM, Canning DA, Liechty KW. Age and pro-inflammatory cytokine production: Woundhealing implications for scar-formation and the timing of genital surgery in boys. Journal of Pediatric Urology. 2011; 7:324-331. [PubMed: 21527214]

Bleustein CB, Fogarty JD, Eckholdt H, Arezzo JC, Melman A. Effect of neonatal circumcision on penile neurological sensation. Urology. 2005; 65:773-777. [PubMed: 15833526]

Bollinger D. Lost boys: An estimate of U.S. circumcision-related infant deaths. Thymos: Journal of Boyhood Studies. 2010; 4:78-90.

Boyle GJ, Hill G. Matters arising: "The case for boosting infant male circumcision in the face of rising heterosexual transmission of HIV"... and now the case against (Letter). The Medical Journal of Australia. 2011; 194:99. [PubMed: 21302380]

Breda, M. Safety, satisfaction, and HIV risk one-year following male circumcision (MC): A retrospective clinical data review from rural Kenya; 6th IAS Conference on HIV Pathogenesis, Treatment and Prevention, 17-20 July; Rome, Italy. 2011; TUPE381

Brick P. How does Europe do it? Family Life Matters. 1999; 36:3. [PubMed: 12321920]

Buchbinder SP, Vittinghoff E, Heagerty PJ, Celum CL, Seage GR 3rd. Judson FN, Koblin BA. Sexual risk, nitrite inhalant use, and lack of circumcision associated with HIV sero-conversion in men who have sex with men in the United States. Journal of Acquired Immune Deficiency Syndromes. 2005; 39:82-89. [PubMed: 15851918]

Castellsague X, Albero G, Cleries R, Bosch FX. HPV and circumcision: A biased, inaccurate and misleading meta-analysis. Journal of Infection. 2007; 55:91-93. [PubMed: 17433445]

Centers for Disease Control and Prevention [CDC]. Racial/ethnic disparities in diagnoses of HIV/ AIDS-33 states, 2001-2005. MMWR. Morbidity and Mortality Weekly Report. 2007; 56:189193. [PubMed: 17347642]

Centers for Disease Control and Prevention [CDC]. HIV/AIDS science facts. Male circumcision and risk for HIV transmission and other health conditions: Implications for the United States. 2008. Retrieved from http://www.cdc.gov/hiv/resources/factsheets/circumcision.htm

Centers for Disease Control and Prevention [CDC]. Diagnoses of HIV infection and AIDS in the United States and Dependent Areas, 2009. 2011a; 21 Retrieved from http://www.cdc.gov/hiv/ surveillance/resources/reports/2009report/index.htm. 
Centers for Disease Control and Prevention [CDC]. Trends in in-hospital newborn male circumcision United States, 1999-2010. Morbidity and Mortality Weekly Report (MMWR). 2011b; 60:11671168.

Cherpes TL, Meyne LA, Krohn MA, Hiller SL. Risk factors for infection with herpes simplex virus type 2: Role of smoking, douching, uncircumcised males, and vaginal flora. Sexually Transmitted Diseases. 2003; 30:405-410. [PubMed: 12916131]

Chin JJ. Matters arising: "The case for boosting infant male circumcision in the face of rising heterosexual transmission of HIV"... and now the case against (Letter). The Medical Journal of Australia. 2011; 194:100-101. [PubMed: 21302382]

Clark SJ, Kilmarx PH, Kretsinger K. Coverage of newborn and adult male circumcision varies among public and private US payers despite health benefits. Health Affairs (Millwood). 2011; 30:23552361.

Collins S, Upshaw J, Rutchik S, Ohannessian C, Ortenberg J, Albertsen P. Effects of circumcision on male sexual function: Debunking a myth? Journal of Urology. 2002; 167:2111-2112. [PubMed: 11956452]

Conroy N. Matters arising: "The case for boosting infant male circumcision in the face of rising heterosexual transmission of HIV"... and now the case against (Letter). The Medical Journal of Australia. 2011; 194:99. [PubMed: 21299016]

Cooper DA, Wodak AD, Morris BJ. The case for boosting infant male circumcision in the face of rising heterosexual transmission of HIV. The Medical Journal of Australia. 2010; 193:318-319. [PubMed: 20854234]

Darby R, Van Howe RS. Not a surgical vaccine: there is no case for boosting infant male circumcision to combat heterosexual transmission of HIV in Australia. Australian and New Zealand Journal of Public Health. 2011; 35:459-465. [PubMed: 21973253]

Darby RL. Matters arising: "The case for boosting infant male circumcision in the face of rising heterosexual transmission of HIV"... and now the case against (Letter). The Medical Journal of Australia. 2011; 194:100. [PubMed: 21299018]

David HP, Morgall JM, Osler M, Rasmussen NK, Jensen B. United States and Denmark: Different approaches to health care and family planning. Studies in Family Planning. 1990; 21:1-19. [PubMed: 2315964]

Dodge B, Sandfort TG, Yarber WL, de Wit J. Sexual health among male college students in the United States and the Netherlands. American Journal of Health Behavior. 2005; 29:172-182. [PubMed: 15698984]

Drevenstedt GL, Crimmins EM, Vasunilashorn S, Finch CE. The rise and fall of excess male infant mortality. Proceedings of The National Academy of Sciences USA. 2008; 105:5016-5021.

Fergusson DM, Boden JM, Horwood LJ. Circumcision status and risk of sexually transmitted infection in young adult males: An analysis of a longitudinal birth cohort. Pediatrics. 2006; 118:1971-1977. [PubMed: 17079568]

Ferris JA, Richters J, Pitts MK, Shelley JM, Simpson JM, Ryall R, Smith AMA. Circumcision in Australia: Further evidence on its effects on sexual health and wellbeing. Australian and New Zealand Journal of Public Health. 2010; 34:160-164. [PubMed: 23331360]

Fink KS, Carson CC, deVellis RF. Adult circumcision outcomes study: Effect on erectile function, penile sensitivity, sexual activity and satisfaction. Journal of Urology. 2002; 167:2113-2116. [PubMed: 11956453]

Fiore AE, Shay DK, Haber P, Iskander JK, Uyeki TM, Mootrey G, Cox NJ. Prevention and control of influenza. Recommendations of the Advisory Committee on Immunization Practices (ACIP), 2007. Centers for Disease Control and Prevention-Mortality and Morbidity Weekly Report. 2007; 56:1-54.

Fleiss PM, Hodges FM, Van Howe RS. Immunological functions of the human prepuce. Sexually Transmitted Infections. 1998; 74:364-367. [PubMed: 10195034]

Forbes DA. Matters arising: "The case for boosting infant male circumcision in the face of rising heterosexual transmission of HIV'. ... and now the case against (Letter). The Medical Journal of Australia. 2011; 194:97. [PubMed: 21241226] 
Fox, M. Analysis: AIDS vaccines experts confused, dismayed. 2007. Retrieved from http:// www.reuters.com/article/europeCrisis/idUSN08226151

Galárraga O, Colchero MA, Wamai RG, Bertozzi SM. HIV prevention cost-effectiveness: A systematic review. BMC Public Health. 2009; 9(Suppl. 1):S5. [PubMed: 19922689]

Gisselquist D, Potterat JJ, St Lawrence JS, Hogan M, Arora NK, Correa M, Ounga T. How to contain generalized HIV epidemics? A plea for better evidence to displace speculation. International Journal of STD \& AIDS. 2009; 20:443-446. [PubMed: 19541883]

Gray R, Kigozi G, Kong X, Ssempiija V, Makumbi F, Wattya S, Wawer MJ. The effectiveness of male circumcision for HIV prevention and effects on risk behaviors in a post-trial follow up study. AIDS. 2012; 26:609-615. [PubMed: 22210632]

Gray RH, Kigozi G, Serwadda D, Makumbi F, Watya S, Nalugoda F, Wawer MJ. Male circumcision for HIV prevention in men in Rakai, Uganda: A randomised trial. Lancet. 2007; 369:657-666. [PubMed: 17321311]

Green LW, McAllister RG, Peterson KW, Travis JW. Male circumcision is not the 'vaccine' we have been waiting for! Future HIV Therapy. 2008; 2:193-199.

Green LW, McAllister RG, Peterson KW, Travis JW. Medicaid coverage of circumcision spreads harm to the poor. American Journal of Public Health. 2009; 99:584. [PubMed: 19150892]

Green LW, Travis JW, McAllister RG, Peterson KW, Vardanyan AN, Craig A. Male circumcision and HIV prevention insufficient evidence and neglected external validity. American Journal of Preventive Medicine. 2010; 39:479-482. [PubMed: 20965388]

Hallett TB, Alsallaq RA, Baeten JM, Weiss H, Celum C, Gray R, Abu-Raddad L. Will circumcision provide even more protection from HIV to women and men? New estimates of the population impact of circumcision interventions. Sexually Transmitted Infections. 2011; 87:88-93. [PubMed: 20966458]

Hankins C. Male circumcision: Implications for women as sexual partners and parents. Reprod Health Matters. 2007; 15:62-67. [PubMed: 17512377]

Health Care Complaints Commission. Public warning about the Australian Vaccination Network (AVN). 2010. Retrieved from http://www.hccc.nsw.gov.au/Publications/Media-Releases/PUBLICWARNING-/default.aspx

Jameson DR, Celum CL, Manhart L, Menza TW, Golden MR. The association between lack of circumcision and HIV, HSV-2, and other sexually transmitted infections among men who have sex with men. Sexually Transmitted Diseases. 2010; 37:147-152. [PubMed: 19901865]

Kang M, Rochford A, Johnston V, Jackson J, Freedman E, Brown K, Mindel A. Prevalence of Chlamydia trachomatis infection among'high risk' young people in New South Wales. Sexual Health. 2006; 3:253-254. [PubMed: 17112436]

Kassler, WJ.; Aral, SO. Beyond risk groups: Behavioral correlates of HIV seroconversion in sexually transmitted disease clinic patients; XI Meeting of the International Society for STD Research; 1995; abstract \#017

Kelly H, Carville K, Grant K, Jacoby P, Tran T, Barr I. Estimation of influenza vaccine effectiveness from routine surveillance data. PLoS One. 2009; 4:5079.

Kigozi G, Watya S, Polis CB, Buwembo D, Kiggundu V, Wawer MJ, Gray RH. The effect of male circumcision on sexual satisfaction and function, results from a randomized trial of male circumcision for human immunodeficiency virus prevention, Rakai, Uganda. BJU International. 2008; 101:65-70. [PubMed: 18086100]

Kim D, Pang MG. The effect of male circumcision on sexuality. BJU International. 2007; 99:11691170.

Kreiss JK, Hopkins SG. The association between circumcision status and human immunodeficiency virus infection among homosexual men. The Journal of Infectious Diseases. 1993; 168:14041408. [PubMed: 8245525]

Krieger JN, Mehta SD, Bailey RC, Agot K, Ndinya-Achola JO, Parker C, Moses S. Adult male circumcision: Effects on sexual function and sexual satisfaction in Kisumu, Kenya. The Journal of Sexual Medicine. 2008; 5:2610-2622. [PubMed: 18761593] 
Larke N, Thomas SL, Dos Santos Silva I, Weiss HA. Male circumcision and human papillomavirus infection in men: A systematic review and meta-analysis. The Journal of Infectious Diseases. 2011a; 204:1375-1390. [PubMed: 21965090]

Larke NL, Thomas SL, Dos Santos Silva I, Weiss HA. Male circumcision and penile cancer: A systematic review and meta-analysis. Cancer Causes Control. 2011b; 22:1097-1110. [PubMed: 21695385]

Laumann EO, Maal CM, Zuckerman EW. Circumcision in the United States. Prevalence, prophyactic effects, and sexual practice. Journal of American Medical Association. 1997; 277:1052-1057.

Leibowitz AA, Desmond K, Belin T. Determinants and policy implications of male circumcision in the United States. American Journal of Public Health. 2009; 99:138-145. [PubMed: 19008503]

Lie RK, Miller FG. What counts as reliable evidence for public health policy: The case of circumcision for preventing HIV infection. BMC Medical Research Methodology. 2011; 11:34. 6 pages. [PubMed: 21453535]

Maine D, Hurlburt S, Greeson D. Cervical cancer prevention in the 21st century: Cost is not the only issue. American Journal of Public Health. 2010; 101:1549-1555. [PubMed: 21778496]

Masood S, Patel HRH, Himpson RC, Palmer JH, Mufti GR, Sheriff MKM. Penile sensitivity and sexual satisfaction after circumcision: Are we informing men correctly? Urologia Internationalis. 2005; 75:62-66. [PubMed: 16037710]

Masters, WH.; Johnson, VE. Human Sexual Response. Little Brown; Boston: 1966.

McAllister RG, Travis JW, Bollinger D, Rutiser C, Sundar V. The cost to circumcise Africa. International Journal of Men's Health. 2008; 7:307-316.

Merrill, CT.; Nagamine, M.; Steiner, C. Circumcisions performed in U.S. community hospitals, 2005: Statistical Brief \#45. Healthcare Cost and Utilization Project. 2008. Retrieved http:// www.ncbi.nlm.nih.gov/books/NBK56311/, 1-9

Michael RT, Wadsworth J, Feinleib J, Johnson AM, Laumann EO, Wellings K. Private sexual behavior, public opinion, and public health policy related to sexually transmitted diseases: A USBritish comparison. American Journal of Public Health. 1998; 88:749-754. [PubMed: 9585739]

Millett GA, Flores SA, Marks G, Reed JB, Herbst JH. Circumcision status and risk of HIV and sexually transmitted infections among men who have sex with men: A meta-analysis. JAMA. 2008; 300:1674-1684. [PubMed: 18840841]

Mor Z, Kent CK, Kohn RP, Klausner JD. Declining rates in male circumcision amidst increasing evidence of its public health benefit. PLoS One. 2007; 2:e861. 4 pages. [PubMed: 17848992]

Morris BJ. Why circumcision is a biomedical imperative for the 21st century. BioEssays. 2007; 29:1147-1158. [PubMed: 17935209]

Morris BJ, Bailis SA, Castellsague X, Wiswell TE, Halperin DT. RACP's policy statement on infant male circumcision is ill-conceived. Australian and New Zealand Journal of Public Health. 2006; 30:16-22. [PubMed: 16502947]

Morris BJ, Bailis SA, Waskett JH, Wiswell TE, Halperin DT. Medicaid coverage of newborncircumcision: A health parity right of the poor. American Journal of Public Health. 2009; 99:969-971. [PubMed: 19372502]

Morris, BJ.; Castellsague, X. The role of circumcision in the prevention of STIs. In: Gross, GE.; Tyring, S., editors. Sexually Transmitted Infections and Sexually Transmitted Diseases. Springer; Heidelberg: 2011. p. 715-739.

Morris, BJ.; Eley, C. Male circumcision: An appraisal of current instrumentation. In: Fazel-Rezai, R., editor. Biomedical Engineering. University of Rijeka, InTech; Rijeka, Croatia: 2011. p. 315-354.

Morris BJ, Gray RH, Castellsague X, Bosch FX, Halperin DT, Waskett JH, Hankins CA. The strong protection afforded by circumcision against cancer of the penis (Invited Review). Advances in Urology. 2011a:1-21. Article ID 812368.

Morris BJ, Waskett JH, Gray RH, Halperin DT, Wamai R, Auvert B, Klausner JD. Exposé of misleading claims that male circumcision will increase HIV infections in Africa. Journal of Public Health in Africa. 2011b; 2(e281):117-122.

Morris BJ, Wamai RG. Biological basis for the protective effect conferred by male circumcision against HIV infection. International Journal of STD \& AIDS. 2012 in press. 
Morris BJ, Waskett JH, Gray RH. Does sexual function survey in Denmark offer any support for male circumcision having an adverse effect? International Journal of Epidemiology. 2012; 41:310-312. [PubMed: 22422464]

Morris BJ, Waskett JH, Banerjee J, Wamai RG, Tobian AAR, Bailis SA, Mindel A. A 'snip' in time: What is the best age to circumcise? BMC Pediatrics. 2012a; 12:20. Epub ahead of print 28 Feb. [PubMed: 22373281]

Morris BJ, Wodak AD, Mindel A, Schrieber L, Duggan KA, Dilly A, Cooper DA. The 2010 RACP policy statement 'Circumcision of infant males' is not evidence-based. Internal Medicine Journal. $2012 \mathrm{~b}$ in press.

Morris BJ, Wodak AD, Mindel A, Schrieber L, Duggan K, Dilly A, Leeder SR. Circumcision Foundation of Australia. Infant male circumcision: An evidence-based policy statement. Open Journal of Preventive Medicine. 2012c; 2:79-82.

Moses S, Bailey RC, Ronald AR. Male circumcision: Assessment of health benefits and risks. Sexually Transmitted Infections. 1998; 74:368-373. [PubMed: 10195035]

Moses S, Nagelkerke NJD, Blanchard JF. Commentary: Analysis of the scientific literature on male circumcision and risk for HIV infection. International Journal of STD \& AIDS. 1999; 10:626-628. [PubMed: 10492434]

National Centre for HIV Eidemiology and Clinical Research [NCHECR]. HIV, viral hepatitis and sexually transmissible infections in Australia. Annual Surveillance Report. 2011. Retrieved from http://www.med.unsw.edu.au/NCHECRweb.nsf/resources/2011/\$file/KIRBY_ASR2011.pdf

O'Farrell N, Egger M. Circumcision in men and the prevention of HIV infection: A 'meta-analysis' revisited. International Journal of STD \& AIDS. 2000; 11:137-142. [PubMed: 10726934]

Paix BR. Matters arising: "The case for boosting infant male circumcision in the face of rising heterosexual transmission of HIV" $\ldots$ and now the case against (Letter). The Medical Journal of Australia. 2011; 194:100. [PubMed: 21302381]

Payne K, Thaler L, Kukkonen T, Carrier S, Binik Y. Sensation and sexual arousal in circumcised and uncircumcised men. The Journal of Sexual Medicine. 2007; 4:667-674. [PubMed: 17419812]

Potts M, Halperin DT, Kirby D, Swidler A, Marseille E, Klausner JD, Walsh J. Reassessing HIV prevention. Science. 2008; 320:749-750. [PubMed: 18467575]

Potts M, Prata N, Walsh J, Grossman A. Parachute approach to evidence based medicine. BMJ. 2006; 333:701-703. [PubMed: 17008675]

Rhodin, JAG. Rhodin's Histology. Oxford University Press; 1974.

Richters J, Smith AM, de Visser RO, Grulich AE, Rissel CE. Circumcision in Australia: Prevalence and effects on sexual health. International Journal of STD \& AIDS. 2006; 17:547-554. [PubMed: 16925903]

Robert C, Zeckhauser R. The methodology of normative policy analysis. Journal of Policy Analysis Management. 2011; 30:613-643.

Russell, T. Non-circumcision a legal risk. Law in Practice, August issue. 2005. Retrieved from http:// www.circumcision.com.au/Further_Information/newsid374/1/Non-Circumcision-a-LegalRisk.aspx

Sanchez T, Finlayson T, Drake A, Behel S, Cribbin M, Dinenno E, Lansky A. Human immunodeficiency virus (HIV) risk, prevention, and testing behaviors-United States, National HIV Behavioral Surveillance System: Men who have sex with men, November 2003-April 2005. MMWR. Surveillance Summaries. 2006; 55:1-16.

Sansom SL, Prabhu VS, Hutchinson AB, An Q, Hall HI, Shrestha RK, Taylor AW. Cost-effectiveness of newborn circumcision in reducing lifetime HIV risk among U.S. males. PLoS One. 2010; 5:e8723. [PubMed: 20090910]

Schober JM, Meyer-Bahlburg HF, Dolezal C. Self-ratings of genital anatomy, sexual sensitivity and function in men using the 'Self-Assessment of Genital Anatomy and Sexual Function, Male' questionnaire. BJU International. 2009; 103:1096-1103. [PubMed: 19245445]

Schoen EJ. Penile cancer in elderly circumcised man. The Journal of Family Practice. 1997; 45:442443. [PubMed: 9374971] 
Schoen EJ. Critique of Van Howe RS. Incidence of meatal stenosis following neonatal circumcision in a primary care setting. Clinical Pediatrics (Phila). 2007; 45:49-54. Clinical Pediatrics (Phila), 46, 86.

Schoen EJ, Colby CJ, To TT. Cost analysis of neonatal circumcision in a large health maintenance organization. Journal of Urology. 2006; 175:1111-1115. [PubMed: 16469634]

Schoen EJ, Oehrli M, Colby CJ, Machin G. The highly protective effect of newborn circumcision against invasive penile cancer. Pediatrics. 2000; 105:e36. 4 pages. [PubMed: 10699138]

Schoen EJ, Wiswell TE, Moses S. New policy on circumcision - Cause for concern. Pediatrics. 2000; 105:620-623. [PubMed: 10699119]

Senol MG, Sen B, Karademir K, Sen H, Saraçoğlu M. The effect of male circumcision on pudendal evoked potentials and sexual satisfaction. Acta Neurologica Belgica. 2008; 108:90-93. [PubMed: 19115671]

Siegfried N, Muller M, Deeks JJ, Volmink J. Male circumcision for prevention of heterosexual acquisition of HIV in men. The Cochrane Database of Systematic Reviews. 2009; CD003362:38.

Smith DK, Taylor A, Kilmarx PH, Sullivan P, Warner L, Kamb M, Mastro TD. Male circumcision in the United States for the prevention of HIV infection and other adverse health outcomes: Report from a CDC consultation. Public Health Reports. 2010; 125(Suppl. 1):72-82. [PubMed: 20408390]

Son H, Song SH, Kim SW, Paick JS. Selfreported premature ejaculation prevalence and characteristics in Korean young males: Community-based data from an internet survey. Journal of Andrology. 2010; 31:540-546. [PubMed: 20671139]

Sorrells ML, Snyder JL, Reiss MD, Eden C, Milos MF, Wilcox N, Van Howe RS. Fine-touch pressure thresholds in the adult penis. BJU International. 2007; 99:864-869. [PubMed: 17378847]

Sullivan PS, Kilmarx PH, Peterman TA, Taylor AW, Nakashima AK, Kamb ML, Mastro TD. Male circumcision for prevention of HIV transmission: What the new data mean for HIV prevention in the United States. PLoS Med. 2007; 4(e223):1162-1166.

Telzak EE, Chiasson MA, Bevier PJ, Stoneburner RL, Castro KG, Jaffe HW. HIV-1 seroconversion in patients with and without genital ulcer disease: A prospective study. Annals of Internal Medicine. 1993; 119:1181-1186. [PubMed: 8239249]

Templeton DJ, Jin F, Mao L, Prestage GP, Donovan B, Imrie J, Grulich AE. Circumcision and risk of HIV infection in Australian homosexual men. AIDS. 2009; 23:2347-2351. [PubMed: 19752714]

Templeton DJ, Millett GA, Grulich AE. Male circumcision to reduce the risk of HIV and sexually transmitted infections among men who have sex with men. Current Opinion in Infectious Diseases. 2010; 23:45-52. [PubMed: 19935420]

Thornton AC, Lattimore S, Delpech V, Weiss HA, Elford J. Circumcision among men who have sex with men in London, United Kingdom: An unlikely strategy for HIV prevention. Sexually Transmitted Diseases. 2010; 38:928-931. [PubMed: 21934567]

Tobian AA, Gray RH. The medical benefits of male circumcision. JAMA. 2011; 306:1479-1480. [PubMed: 21972310]

Tobian AA, Gray RH, Quinn TC. Male circumcision for the prevention of acquisition and transmission of sexually transmitted infections: The case for neonatal circumcision. Archives of Pediatrics \& Adolescent Medicine. 2010; 164:78-84. [PubMed: 20048246]

Travis JW, Buckley SJ, Mason P, McGrath K, Van Howe RS, Williams G. Matters arising: "The case for boosting infant male circumcision in the face of rising heterosexual transmission of HIV" ... and now the case against (Letter). The Medical Journal of Australia. 2011; 194:97-98. [PubMed: 21302379]

UNAIDS. Safe, Voluntary, Informed Male Circumcision and Comprehensive HIV Prevention Programming: Guidance for decision-makers on human rights, ethical \& legal considerations. 2007. Retrieved from http://data.unaids.org/pub/Manual/ 2007/070613_humanrightsethicallegalguidance_en.pdf

UNAIDS. Global Report: UNAIDS Report on the Global AIDS Epidemic. 2010. Retrieved from http:// www.unaids.org/en/media/unaids/contentassets/documents/unaidspublication/ 2010/20101123_globalreport_en[1].pdf 
UNAIDS/WHO/SACEMA Expert Group on Modelling the Impact and Cost of Male Circumcision for HIV Prevention. Male circumcision for HIV prevention in high HIV prevalence settings: What can mathematical modelling contribute to informed decision making? PLoS Med. 2009; 6:e1000109. [PubMed: 19901974]

Uthman OA, Popoola TA, Uthman MM, Aremu O. Economic evaluations of adult male circumcision for prevention of heterosexual acquisition of HIV in men in sub-Saharan Africa: A systematic review. PLoS One. 2010; 5:e9628. [PubMed: 20224784]

Van Howe RS. Circumcision and HIV infection: Review of the literature and meta-analysis. International Journal of STD \& AIDS. 1999; 10:8-16. [PubMed: 10215123]

Van Howe RS, Storms MR. How the circumcision solution in Africa will increase HIV infections. Journal of Public Health in Africa. 2011; 2(e4):11-15.

Waldinger MD, McIntosh J, Schweitzer DH. A five-nation survey to assess the distribution of the intravaginal ejaculatory latency time among the general male population. The Journal of Sexual Medicine. 2009; 6:2888-2895. [PubMed: 19627471]

Waldinger MD, Quinn P, Dilleen M, Mundayat R, Schweitzer DH, Boolell M. A multinational population survey of intravaginal ejaculation latency time. The Journal of Sexual Medicine. 2005; 2:492-497. [PubMed: 16422843]

Wallace, A. An epidemic of fear: How panicked parents skipping shots endangers us all. 2009. Retrieved from http://www.wired.com/magazine/2009/10/ff_waronscience/

Wallace HM, Vienonen M. Teenage pregnancy in Sweden and Finland. Implications for the United States. Journal of Adolescent Health Care. 1989; 10:231-236. [PubMed: 2715098]

Walter G, Streimer J. Genital self-mutilation: Attempted foreskin reconstruction. The British Journal of Psychiatry. 1990; 156:125-127. [PubMed: 2404537]

Wamai R, Morris BJ. 'How to contain generalized HIV epidemics' article misconstrues the evidence. International Journal of STD \& AIDS. 2011; 22:415-416. [PubMed: 21729966]

Wamai RG, Morris BJ, Bailis SA, Sokal D, Klausner JD, Appleton R, Banerjee J. Male circumcision for HIV prevention - current evidence and implementation in sub-Saharan Africa. Journal of the International AIDS Society. 2011; 14:49. 17 pages. [PubMed: 22014096]

Wamai RG, Weiss HA, Hankins C, Agot K, Karim QA, Shisana O, Halperin DT. Male circumcision is an efficacious, lasting and cost-effective strategy for combating HIV in high-prevalence AIDS epidemics: Time to move beyond debating the science. Future HIV Therapy. 2008; 2:399-405.

Wang ML, Macklin EA, Tracy E, Nadel H, Catlin EA. Updated parental viewpoints on male neonatal circumcision in the United States. Clinical Pediatrics (Phila). 2010; 49:130-136.

Warner L, Ghanem KG, Newman DR, Macaluso M, Sullivan PS, Erbelding EJ. Male circumcision and risk of HIV infection among heterosexual African American men attending Baltimore sexually transmitted disease clinics. The Journal of Infectious Diseases. 2009; 199:59-65. [PubMed: 19086815]

Waskett JH, Morris BJ. Fine-touch pressure thresholds in the adult penis. (Critique of Sorrells ML, et al. BJU Int 2007;99:864-869). BJU International. 2007; 99:1551-1552. [PubMed: 17537227]

Waskett JH, Morris BJ. Re: 'RS Van Howe, FM Hodges. The carcinogenicity of smegma: Debunking a myth. 'An example of myth and mythchief making? (Letter to the Editor). Journal of the European Academy of Dermatology and Venereology. 2008; 22:131. [PubMed: 18182000]

Waskett JH, Morris BJ, Weiss HA. Errors in meta-analysis by Van Howe. International Journal of STD \& AIDS. 2009; 20:216-218. [PubMed: 19255281]

Wawer MJ, Gray RH, Serwadda D, Kigozi G, Nalugoda F, Quinn TC. Male circumcision as a component of human immunodeficiency virus prevention. American Journal of Preventive Medicine. 2011; 40:e7-e8. [PubMed: 21335256]

Wawer MJ, Makumbi F, Kigozi G, Serwadda D, Watya S, Nalugoda F, Gray RH. Circumcision in HIV-infected men and its effect on HIV transmission to female partners in Rakai, Uganda: A randomised controlled trial. Lancet. 2009; 374:229-237. [PubMed: 19616720]

Weinberg MS, Lottes IL, Aveline D. AIDS risk reduction strategies among United States and Swedish heterosexual university students. Archives of Sexual Behavior. 1998; 27:385-401. [PubMed: 9681120] 
Weiss HA, Hankins CA, Dickson K. Male circumcision and risk of HIV infection in women: A systematic review and meta-analysis. The Lancet Infectious Diseases. 2009; 9:669-677. [PubMed: 19850225]

Weiss HA, Larke N, Halperin D, Schenker I. Complications of circumcision in male neonates, infants and children: A systematic review. BMC Urology. 2010; 10:2. 13 pages. [PubMed: 20158883]

Weller S, Davis K. Condom effectiveness in reducing heterosexual HIV transmission. The Cochrane Database of Systematic Reviews. 2001:CD003255. [PubMed: 11687062]

Westercamp, N.; Bailey, RC.; Agot, K. Sexual function and satisfaction improve six months after circumcision among men in Nzanza province, Kenya; 6th IAS Conference on HIV Pathogenesis, Treatment and Prevention, 17-20 July; Rome, Italy. 2011; TUPE384

WHO and JHPIEGO. Manual for early infant male circumcision under local anaesthesia. 2010. Retrieved from http://whqlibdoc.who.int/publications/2010/9789241500753_eng.pdf

Wikipedia. Vaccine controversy. 2011. Retrieved from http://en.wikipedia.org/wiki/ Vaccine_controversy

Willcourt R. Critique of: 'The effect of male circumcision on sexuality' [Kim KD, \& Pang M. BJU Int 2006;99:619-622]. BJU International. 2007; 99:1169-1170. [PubMed: 17437447]

Wiysonge CS, Kongnyuy EJ, Shey M, Muula AS, Navti OB, Akl EA, Lo YR. Male circumcision for prevention of homosexual acquisition of HIV in men. The Cochrane Database of Systematic Reviews. 2011; 6:CD007496. [PubMed: 21678366]

Xu F, Markowitz LE, Sternberg MR, Aral SO. Prevalence of circumcision and herpes simplex virus type 2 infection in men in the United States: The National Health and Nutrition Examination Survey (NHANES), 1999-2004. Sexually Transmitted Diseases. 2007; 34:479-484. [PubMed: 17413536]

Zetola N, Klausner JD. Male circumcision reduces human papillomavirus incidence and prevalance: Clarifying the evidence. Sexually Transmitted Diseases. 2012; 39:114-115. [PubMed: 22249299] 


\section{Table 1}

Infant mortality (IM) rates (deaths per 1,000 live births) for selected countries for which neonatal MC rate is known

\begin{tabular}{lrccc}
\hline Country & Est. neonatal MC rate & IM (male) & IM (female) & IM (m:f ratio) \\
\hline Israel & $>90 \%$ & 4.1 & 3.9 & 1.05 \\
Nigeria & $80-90 \%$ & 97 & 85 & 1.14 \\
USA & $60-80 \%$ & 6.7 & 5.4 & 1.25 \\
Australia & $\mathrm{B} 20 \%$ & 4.6 & 3.6 & 1.28 \\
UK & $<5 \%$ & 5.1 & 4.2 & 1.22 \\
France & $<5 \%$ & 3.6 & 3.0 & 1.22 \\
Denmark & $<5 \%$ & 3.7 & 3.0 & 1.23 \\
Norway & $<5 \%$ & 3.7 & 2.6 & 1.42 \\
Finland & $<1 \%$ & 3.7 & 3.1 & 1.20 \\
\hline
\end{tabular}

Notes: Figures used for calculations were from: CIA World Factbook, https://www.cia.gov/library/publications/the-world-factbook/fields/ 2091.html; United Nations Economic Commission for Europe, http://w3.unece.org/pxweb/dialog/varval.asp? ma=003_GEHEInfantDeath_r\&path=../database/STAT/30-GE/06-Health/\&lang=1\&ti=Infant+mortality+rate+by+sex); Australian Bureau of Statistics, http://www.abs.gov.au/ausstats/abs@.nsf/Lookup/by\%20Subject/1370.0 2010 Chapter Infant\%20mortality\%20(4.1.3); UNICEF, http://www.childinfo.org/statistical_tables.html; Inter-agency Group for Child Mortality Estimation, http://www.childmortality.org/; Population Reference Bureau, https://www.prb.org/datafinder.aspx 